\title{
IbM kelompok usaha ikan salai lele dan kerupuk ikan
}

\author{
Mery Sukmiwati*, N Ira Sari, \& Dahlia \\ Fakultas Perikanan dan Ilmu Kelautan,Universitas Riau \\ * merysarmin@yahoo.com
}

\begin{abstract}
Abstrak. Penyuluhan dan pelatihan pada kelompok usaha ikan salai lele dan kerupuk ikan bertujuan memahami Cara Produksi Pangan yang Baik untuk Industri Rumah Tangga (CPPB-IRT) yang merupakan faktor penting untuk memenuhi standar mutu berguna bagi kelangsungan hidup industri pangan, baik yang berskala kecil, sedang, maupun yang berskala besar. Melalui CPPB ini industri pangan dapat menghasilkan pangan yang bermutu, layak dikonsumsi dan aman bagi kesehatan. Ada 3 metode pendekatan yang dilakukan yaitu: metode penyuluhan meliputi: CPPB untuk meningkatkan keamanan pangan, mutu pangan dan umur simpan produk. Metode pelatihan meliputi: pembuatan produk ikan salai dan kerupuk ikan, metode pendampingan: pengurusan izin Usaha dan Produksi ke Dinas Kesehatan. Hasil penyuluhan dan pelatihan bahwa permasalahan cerobong asap sudah direnovasi, sehingga asap yang muncul saat pembakaran sudah dibuang keluar ruangan. Telah dilakukan penyuluhan CPPB- IRT dan manajemen wirausaha mikro terpadu untuk kedua mitra, telah dilaksanakan penyuluhan penanganan, pengolahan ikan segar, penyimpanan ikan dan membantu pembuatan desain kemasan kerupuk dan pelabelan. Membantu pengurusan izin P-IRT dari Dinas Kesehatan. Target yang hendak dicapai pada produk ikan salai dan kerupuk ikan harus memenuhi (SNI 1992) ikan asap dan (SNI 1999) kerupuk ikan.
\end{abstract}

Kata kunci: CPPB; izin P-IRT; ikan salai; kerupuk ikan

\begin{abstract}
Counseling and training at business group of smoked fish and fish cracker were aimed to understanding how to produce good food for home industries is an important factor for quality standards useful for the continuation of the food industry, Through this CPPB the food industry can produce quality food, suitable for consumption and safe for health. There are 3 methods of approach taken, namely: extension methods include: CPPB to improve food security, food quality and product shelf life. Training methods include: making smoked fish products and fish crackers, accompaniment methods: managing business and production permits to the Health Office. The results of counseling and training that the problem of the chimney has been renovated, so that the smoke appears when burning has been thrown out of the room. CPPB-IRT counseling and integrated micro entrepreneurship management have been carried out for both partners. It has been carried out counseling on handling, processing fresh fish, storing fish and assisting in making cracker packaging and labeling designs. Assist in obtaining P-IRT permit from the Health Office. Targets to be achieved on smoked fish products and fish crackers must meet smoked fish (SNI 1992) and (SNI 1999) fish crackers.
\end{abstract}

Keywords: CPPB; Permit for P-IRT; fish crackers; smoked fish

To cite this article: Sukmiwati, M., N. I. Sari, \& Dahlia. 2019. IbM kelompok usaha ikan salai lele dan kerupuk ikan. Unri Conference Series: Community Engagement 1: 639-644 https://doi.org/10.31258/unricsce.1.639-644

\section{(C) 2019 Authors}

Peer-review under responsibility of the organizing committee of Seminar Nasional Pemberdayaan Masyarakat 2019 


\section{PENDAHULUAN}

Khalayak sasaran dalam program PPM yang berbasis Ipteks bagi Masyarakat (IbM) Kelompok usaha ikan salai Lele dan Kerupuk Ikan adalah masyarakat yang produktif secara ekonomi (usaha mikro) adalah : 1) Bapak Ahmaddin Margolang; 2) Bapak Patudin. Tujuan dari IbM Kelompok usaha ikan salai Lele dan Kerupuk Ikan adalah untuk menjadikan UKM mengetahui CPPB-IRT dalam usaha ikan salai Lele dan Kerupuk Ikan; untuk memahami dan mengerti manajemen wirausaha mikro terpadu dan terintegrasi, dan embuat produk ikan salai dan kerupuk yang memenuhi standar SNI. Bapak Ahmaddin Margolang merupakan wirausahawan dibidang produksi dan pemasaran ikan lele asap dan produk- produk ikan asap lainnya. Usaha pengasapan ikan lele bapak Ahmaddin diberi nama Usaha Pengasapan "Bakat" yang terletak di jalan Penerbangan Nomor 130 RT 05/RW 08 Kelurahan Simpang Tiga Kecamatan Bukit Raya Kota Pekanbaru. Lokasi ini terbilang strategis karena tidak jauh dari beberapa pasar tradisional dan swalayan sehingga memudahkan untuk melakukan distribusi produk.

Usaha pengasapan "Bakat" didirikan pada tahun 2011 oleh Ahmaddin Margolang S.Pi. Sebelum mendirikan usaha pengasapan ikan lele tersebut, Ahmaddin telah terlebih dahulu mendirikan usaha budidaya pembesaran ikan lele di kolam. Setelah 2 tahun menjalankan usaha kolam pembesaran lele, sejalan dengan itu, areal pemeliharaan dan produksi terus meningkat sehingga pemasaran produk mulai mengalami hambatan. Untuk mengatasi permasalahan tersebut sekaligus meningkatkan dan pengembangkan usaha yang tidak sebatas pemasaran ikan lele hidup saja maka pemilik usaha ini, pada tahun 2011 mendirikan industri pengasapan ikan. Pada waku itu ikan asap jarang yang dibuat dari ikan lele, sehingga penerimaan konsumen dan pasar sangat rendah, dan hal ini merupakan salah satu masalah saat itu, namun dengan keyakinan dan kegigihan Bapak Ahmaddin Margolang yang selalu mempromosikan produk ikan lele asap tersebut, sehingga akhirnya ikan lele asap dapat diterima dipasaran dan diterima oleh selera konsumen. Produksi ikan lele perhari rata-rata sebesar $110 \mathrm{~kg}$. Ikan lele dijual dalam bentuk segar sebanyak $50 \mathrm{~kg}$ setiap harinya dengan harga Rp 13.500 per $\mathrm{kg}$ dan $60 \mathrm{~kg}$ sisanya diolah menjadi ikan asap. Sementara itu kapasitas produksi alat pengasapan yang dimiliki oleh usaha ini adalah $50 \mathrm{~kg}$ perhari. Daya tampung dari rumah asap yang digunakan sangat membatasi jumlah produksi ikan asap yang harus diasap setiap harinya,sehingga perlu pengaturan yang tepat dalam penyusunan dan penempatan ikan yang harus diasap diruang yang terbatas kapasitasnya.

Bapak Pudin adalah seorang pengusaha produk kerupuk ikan, dengan nama usaha olahannya yaitu Usaha pengolahan kerupuk ikan "Cobi Raosan" terletak di jalan Kayu Aro RT 001 RW 008 Dusun IV Desa Tanah Merah Simpang Pandau Kecamatan Siak Hulu Kabupaten Kampar, usaha tersebut merupakan Industri rumah tangga yang dimulai pada tahun 2000 oleh pasangan Patudin dan Mumun. Pada awalnya, usaha pengolahan ini dilakukan sendiri oleh suami istri tersebut, kemudian berapa tahun sejumlah tenaga kerja direkrut dan pada saat ini tenaga kerja berjumlah 14 orang. Aktifitas usaha dilakukan dalam gedung berukuran 9 x 8 meter dan menggunakan alat-alat pengolahan sederhana. Usaha pengolahan ini terus meningkat setiap tahun dengan produksi rata-rata perhari saat ini adalah kerupuk Palembang/ ikan $\pm 50 \mathrm{~kg}$ dan kerupuk nasi $\pm 50 \mathrm{~kg}$ produk jadi. Usahanya diberi nama "COBI RAOSAN" dari bahasa sunda yang artinya coba rasakan.

\section{Masalah yang dihadapi mitra 1 (Bapak Ahmaddin Margolang):}

1. Dari hasil pengamatan langsung ke lokasi tempat pengasapan di lihat dari sisi keamanan lingkungan, bahwa cerobang asap yang digunakan sebagai tempat pembuangan asap, seharusnya dialirkan ke ruang luar yang terbuka agar asap yang dihasilkan tidak menganggu lingkungan sekitarnya, terutama karyawan yang berada didalam ruang pengolahan dan pengasapan. Perlu perubahan alat pengasapan yang standar digunakan, layak untuk usaha home industri

2. Kurangnya daya tampung oven pengasapan ikan, sehingga waktu pengasapan bertambah lebih lama dan ikan yang diasap tidak merata, karena harus dipaksakan jumlah ikan yang banyak dengan kondisi ruang asap yang tidak memadai sehingga produk ikan lele asap yang dihasilkan mutunya tidak sama.

3. Dengan mutu produk ikan asap yang tidak sama(bervariasi), menyebabkan waktu kadaluarsa produk juga berbeda, hal ini disebabkan sebagian produk telah rusak sebelum tanggal kadaluarsa, sehingga tidak menjamin produk olahan ikan lele asap masih baik sampai ke tangan konsumen.

4. Belum adanya jaringan pemasaran yang banyak dan terkoordinir dilakukan, sehingga pemasarannya terbatas untuk konsumsi daerah Pekanbaru saja.

5. Desain kemasan dan label dari produk ikan lele asap belum mampu bersaing dan belum mendapat tempat dipasaran dan hati konsumen, oleh karena itu perlu perbaikan, perlu menampilkan nilai estetika, nilai kepraktisan untuk mendapatkan nilai jual yang tinggi. 
6. Keterbatasan modal untuk pengembangan alat pengasapan/ rumah asap yang memenuhi standar Sanitasi dan hygenis dan tidak menimbulkan dampak ataupun polusi udara pada lingkungan sekitarnya.

\section{Masalah yang dihadapi mitra 2 (Bapak Patudin)}

1. Kemasan yang ada tidak dapat mendongrak nilai jual dari kerupuk ikan ini. Sehingga distribusi pasarnya hanya tingkat pasar-pasar yang tradisional, sulit untuk menembus pasar setingkat swalayan atau supermarket disebabkan kemasan kerupuk ini sangat sederhana sekali, oleh karena itu perlu kemasan dan pelabelan yang sesuai dengan standarisasi label pangan. Kemasan dengan mengunakan plastik kadangkala tidak dapat menjamin keaadan kerupuk setelah sampai pada daerah tujuan yang relative jauh, seringkali timbul complain dari pedagang eceran atau dari konsumen sendiri.

2. Daerah pemasaran kerupuk terutama daerah-daerah pinggiran yang cukup jauh, sedangkan transportasi yang digunakan untuk mendistribusikan kerupuk ke daerah-daerah pinggiran hanya menggunakan transportasi sepeda motor, yang kapasitas untuk membawa kerupuk sangat terbatas jumlahnya.

3. Keterbatasan modal usaha Bapak Pudin jika ingin mengembangkan usaha pengolahan kerupuk ikan agar lebih banyak produksinya setiap hari, atau jika ada pesanan dalam jumlah yang besar sulit untuk dipenuhi.

\section{METODE PELAKSANAAN}

\section{Tempat dan waktu pelaksaan}

Tempat kegiatan IbM mitra pertama dilakukan di Jl. Gading Marpoyan Kelurahan Simpang Tiga, Kec. Bukit Raya, Pekanbaru. Tempat kegiatan IbM mitra kedua dilakukan di Jl. Kayu Aro Dusun IV Desa Tanah Merah, Kec. Siak Hulu, Kampar. Kegiatan in dilakukan selama 12 bulan pada tahun 2015.

\section{Metode pendekatan}

Ada 3 metode pendekatan yang ditawarkan untuk menyelesaikan persoalan mitra program yang telah disepakati bersama untuk kedua aspek utama (produksi dan manajemen) dalam kurun waktu realisasi program IbM yaitu:

1. Metode Penyuluhan:

Materi penyuluhan yang akan diberikan meliputi:

a. Cara memproduksi pangan yang baik untuk meningkatkan keamanan pangan, mutu pangan dan umur simpan produk ikan asap dan kerupuk ikan.

b. Manajemen wirausaha mikro terpadu dan terintegrasi: manajemen produksi, sumber daya manusia dan pemasaran.

2. Metode Pelatihan/ Metode Demonstrasi:

Materi pelatihan yang akan diberikan meliputi:

a. Penanganan dan Pengolahan ikan\

b. Pembuatan produk ikan salai/asap dan kerupuk ikan

c. Pembuatan Spesifikasi produk ikan salai/ asap dan kerupuk ikan

d. Pembuatan kemasan dan label produk ikan salai/asap dan kerupuk ikan.

3. Metode Pendampingan

Materi pendampingan yang akan dilakukan meliputi:

a. Produksi ikan asap dan kerupuk ikan skala UKM

b. Pelaksanaan manajemen wirausaha (produksi, SDM dan pemasaran)

c. Pengurusan Ijin Usaha dan Produksi ke Departemen Kesehatan Pekanbaru.

\section{Metode yang ditawarkan}

1. Prosedur kerja untuk mendukung realisasi metode yangditawarkan adalah sebagai berikut:

a. Penyuluhan Cara Produksi Makanan yang baik.

Cara produksi pangan yang baik untuk industri rumah tangga (CPPB-IRT) yang akan disampaikan sesuai dengan pedoman CPPB-IRT dari Badan Pengawasan Obat dan Makanan, yang isinya adalah sebagai berikut : Cara Produksi Pangan yang Baik untuk Industri Rumah Tangga (CPPB-IRT) menyelaskan persyaratan-persyaratan yang harus dipenuhi tentang penanganan bahan pangan di seluruh mata rantai produksi pangan mulai bahan baku sampai produk akhir. Cara Produksi Pangan yang Baik (CPPB) merupakan salah satu faktor yang penting untuk memenuhi standar mutu atau persyaratan yang ditetapkan untuk pangan CPPB sangat berguna bagi kelangsungan hidup industri pangan, baik 
yang berskala kecil, sedang, maupun yang berskala besar. Melalui CPPB ini industri pangan dapat menghasilkan pangan yang bermutu, layak dikonsumsi dan aman bagi kesehatan.

b. Penanganan dan pengolahan Ikan Segar

Dalam proses pembuatan ikan asap harus mengacu pada standar penetapan dan penanganan ikan asap Bagian 2. Persyaratan bahan baku dengan acuan normative SNI 2725.2:2009. Penanganan yang dimaksud adalah kegiatan/perlakuan terhadap ikan tanpa mengubah struktur dan bentuk dasar. Pengolahan yang dimaksud adalah kegiatan/perlakuan dari bahan baku ikan sampai menjadi produk akhir untuk konsumsi manusia. Bahan Baku ikan asap harus sesuai dengan SNI 2725.2:2009. Bahan penolong/bahan pelengkap ikan asap, yaitu garam yang bersih sesuai dengan SNI 01-4435-2000. Air yang dipakai sebagai bahan penolong untuk kegiatan pengolahan sesuai dengan ketentuan tentang syarat-syarat untuk pengawasan kualitas air minum sesuai dengan SNI 2725.3:2009.

Dalam pembuatan kerupuk ikan harus mengacu pada standar penetapan dan penanganan ikan untuk kerupuk ikan Bagian 1: Spesifikasi dengan acuan normative SNI 2713.1:2009 dan untuk kerupuk ikan Bagian 2: Persyaratan Bahan Baku mengacu pada SNI 2713.2:2009..

\section{PEMBAHASAN}

\section{Pembuatan cerobong asap sesuai SOP pengolahan}

Kegiatan yang sudah dikerjakan selama pengabdian Ipteks ini yang dapat tuliskan pada lapran akhir antara lain adalah pembuatan cerobong asap pada oven pengasapan yang dibuat sesuai dengan Standar Operasional Prosedur Pengolahan Ikan asap. Sebelum pengabdian ini dilakukan pada tempat pengolahan ikan salai asap terlihat bahwa cerobong asap yang digunakan sebagai tempat pembuangan asap dahulunya dialirkan atau dibuang begitu saja pada ruang pengasapan, sehingga asap yang keluar dapat mengakibatkan polusi udara bagi karyawan yang ada diruang pengasapan tersebut dan juga bagi masyarakat yang tinggal disekitar tempat pengolahan ikan asap. Bila kita lihat dari sisi kesehatan polusi asap dapat membahayakan karyawan pengolahan itu sendiri dan masyarakat sekitarnya.

Dalam saluran napas ada sistem kompleks yang tugasnya menyapu kotoran, debu, atau kuman. Asap ini akan merusak silia dalam saluran napas sehingga sistem pertahanan tubuh di saluran napas turun. Dalam jangka panjang, rusaknya pusat pertahanan alami saluran napas ini akan mempermudah masuknya kuman. "Akibatnya daya tahan tubuh lebih lemah, kalau ada kuman yang berbahaya seperti kuman Tuberculosis yang tadinya bisa dilemahkan menjadi mudah masuk (Ana , L.K. 2013). Dengan dilakukan pengabdian pada masyarakat, diharapkan salah satu bentuk hasilnya adalah kita sudah dapat menyelamatkan sesorang/karyawan pengolahan ikan asap dari lemahnya daya tahan tubuh akibat selalu menghirup asap. Perubahan yang terjadi pada tempat pengolahan ikan asap yaitu asap yang tadinya dibuang didalam ruang pengasapan, tapi sekarang sudah dibuang langsung ke udara terbuka atau ke luar ruangan.

Kelemahan-kelemahan pada pengasapan tradisional diantaranya: waktu persiapannya cukup lama, waktu pengasapan tidak terkontrol kualitasnya tergantung pada jumlah kayu dan kualitas kayu bakar yang digunakan, memberikan peluang resiko kebakaran dan waktu optimum serta suhu pengasapan tidak dapat dipertahanankan.

Kelebihan-kelebihan pada pengasapan tradisional yang dibuat model baru dengan tambahan cerobong asap diantaranya: asap yang keluar bisa dialirkan keluar ruangan dan tidak menyebar kedalam ruang produksi, panas yang ada didalam ruang pengasapan stabil.

\section{Pemberian penyuluhan CPPB-IRT dan manajemen wirausaha mikro terpadu dan terintegrasi pada kedua mitra}

Penyuluhan mengenai Cara Produksi Produk Pangan yang baik dan manajemen Wirausaha Mikro terpadu dan Terintegrasi telah dilakukan pada kedua mitra. Penyuluhan CPPB-IRT diikuti oleh 14 orang pada penyuluhan usaha ikan salai lele dan 13 orang pada penyululuhan usaha kerupuk ikan dapat dilihat pada daftar hadir peserta pada (Lampiran 1 dan Lampiran 2), yang terdri dari masyarakat pengolah ikan asap yang berada disekitar tempat pengolahan ini bahkan ada yang berada di lokasi pengolah yang agak jauh, tetapi merupakan teman sejawat mitra yang sama-sama pengolah juga hadir pada saat penyuluhan CPPB- IRT ini diadakan.

Dari hasil evaluasi penyuluhan CPPB-IRT terlihat masyarakat pengolah yang ikut serta mengikuti penyuluhan CPPB- IRT berlangsung sangat antusias, baik penyuluhan yang diadakan pada usaha ikan salai lele maupun penyuluhan yang diadakan pada usaha kerupuk ikan dimana terlihat semua peserta berperan aktif dalam sesi tanya jawab dan diskusi yang disediakan waktunya sehubungan dengan materi yang diberikan. 
Sebelum jadwal penyuluhan berakhir maka kami bagikan kepada para peserta buku panduan CPPB - IRT, dengan tujuan agar para peserta yang mengikuti penyuluhan dapat kembali mempelajari dan mengingat kembali di rumah apa yang sudah dijelaskan waktu penyuluhan dan untuk dapat mengingat bagian yang penting yang harus di ikuti jika suatu industri rumah tangga ingin mengurus izin P-IRT. Disamping itu kami juga membekali para peserta dengan Pengetahuan praktis mengenai membuat laporan produksi dan laporan keuangan, yang termasuk dalam materi manajemen wirausaha mikro terpadu dan terintegrasi yang disampaikan oleh salah seorang anggota tim kami.

\section{Kegiatan penanganan, pengolahan ikan serta pembuatan ikan salai dan kerupuk ikan}

Kegiatan berikutnya yang sudah dilakukan adalah pelatihan pengolahan ikan segar terhadap pengolah ikan Salai Lele dan pembuatan kerupuk ikan. Dari isi pelatihan kita coba untuk mendemonstrasikan cara penganan dan pengolahan ikan segar kemudian dilanjutkan untuk pembuatan ikan salai atau pembuatan kerupuk ikan.

Tahap penanganan dan penyimpanan menentukan nilai jual dan proses pemanfaatan selanjutnya serta mutu produk olahan ikan yang dihasilkan. Salah satu faktor yang menentukan nilai jual ikan dan hasil perikanan yang lain adalah tingkat kesegarannya. Tingkat kesegaran ikan terkait dengan cara penanganan ikan. Ikan segar adalah ikan yang masih mempunyai sifat yang sama seperti ikan hidup baik rupa, bau, rasa maupun teksturnya. Proses pengasapan yang dlakukan pad usaha ikan salai asap telah memenuhi dasar-dasar pengolah dan pengawetan ikan dengan metoda pengasapan panas.

\section{Pembuatan kemasan dan label produk kerupuk ikan}

Salah satu permasalahan dari pengamatan langsung ke lokasi mitra ke 2 adalah kemasan dan label dari produk kerupuk ikan yang belum mampu bersaing dan belum mendapat tempat dipasaran dan dihati konsumen. Sehingga tidak dapat mendokrak nilai jual dari kerupuk ikan ini, rendahnya nilai jual suatu produk antara lain tidak dikemas dengan baik.

Fungsi paling mendasar dari kemasan adalah untuk mewadahi dan melindungi produk dari kerusakankerusakan, sehingga lebih mudah disimpan, diangkut dan dipasarkan. Secara umum fungsi pengemasan pada bahan pangan adalah :

1. Mewadahi produk selama distribusi dari produsen hingga kekonsumen, agar produk tidak tercecer, terutama untuk cairan, pasta atau butiran

2. Melindungi dan mengawetkan produk, seperti melindungi dari sinar ultraviolet, panas, kelembaban udara, oksigen, benturan, kontaminasi dari kotoran dan mikroba yang dapat merusak dan menurunkan mutu produk.

3. Sebagai identitas produk, dalam hal ini kemasan dapat digunakan sebagai media komunikasidan informasi kepada konsumen melalui label yang terdapat pada kemasan.

4. Meningkatkan efisiensi, misalnya: memudahkan penghitungan, memudahkan pengiriman dan penyimpanan.

5. 5 Melindungi pengaruh buruk dari luar, Melindungi pengaruh buruk dari produk di dalamnya, misalnya jika produk yang dikemas berupa produk yang berbau tajam, atau produk berbahaya seperti air keras, gas beracun

6. Memperluas pemakaian dan pemasaran produk, misalnya penjualan kecap dan syrup mengalami peningkatan sebagai akibat dari penggunaan kemasan botol plastik.

7. Menambah daya tarik calon pembeli

8. Sarana informasi dan iklan.

Begitu pentingnya kemasan dalam perdagangan, membuat setiap produsen terus berinovasi menciptakan kemasan-kemasan yang fungsional dan menarik. Pada tahap ini tim pelaksana pengabdian membantu mitra usaha kerupuk untuk membuat kemasan yang memenuhi standar keamanan pangan dengan pelabelan yang mengikuti standar yang sudah ditentukan. Selain itu juga kita membantu dalam mencetak kemasan setelah izin P-IRT dikeluarkan.

\section{Pengurusan izin P-IRT}

Untuk mendapatkan SPP-IRT diberikan apabila P-IRT masuk dalam level I dan II. Oleh karena untuk memenuhi kriteria penilaian yang bagus, maka sebelum tim survey mengunjungi lokasi pembuatan kerupuk ikan, yang mana sebelumnya lantai tempat pembuatan/pengohan kerupuk ikan masih berlantai tanah, kemudian terlihat langit dan ventilasi dinding tempat pengolah yang sudah tidak terawat, kotor serta berdebu. Melihat kondisi yang demikian yang tidak sesuai dengan isi CPPB-IRT, maka tim pelaksana pengabdian memberikan bantuan dana untuk penyemenan lantai dengan semen yang dibuat sedikit miring agar air dapat 
mengalir selain itu juga tim memberikan bantuan dana untu pembelian cat putih untuk dinding pengolahan dan ventilasi agar lebih kelihatan bersih. Semua upaya ini dilakukan bertujuan agar tempat produksi atau tempat pengolahan layak untuk mendapatkan sertifikat keamanan pangan dan izin P-IRT.

\section{KESIMPULAN}

\section{Simpulan}

Tingkat ketercapaian dalam kegiatan IbM ini adalah 100\%. Dampaknya adalah telah dilakukan perubahan terhadapa alat rumah asap yang sebelumnya asap menyebar kemana-mana ketika dilakukannya pengasapan, setelah dilakukan perombakan dengan menambah cerobong asap maka asap dapat dialirkan keluar ruangan, sangat berdampak positif terhadap kesehatan pekerja. Pada usaha kerupuk ikan, sebelum dilakukannya kegiatan IbM kemasannya belum memenuhi standar keamanan pangan dan pelabelan. Setelah dilakukannya kegiatan IbM pada usaha kerupuk ikan maka kemasan sudah memenuhi standar keamanan pagan dan pelabelan dan telah keluarnya izin P-IRT untuk usah kerupuk ikan. Telah dilaksanakan kegiatan Ipteks bagi masyarakat pada kelompok usaha ikan salai lele dan kerupuk ikan di tempat pengolahan masing-masing adalah sebagai berikut:

1. Pembuatan cerobong asap dimana asap sudah dialirkan ke luar untuk mitra 1.

2. Penyuluhan Cara produksi produk pangan yang baik dan Manajemen wirausaha Mikro terpadu dan terintegrasi untuk kedua mitra (mitra 1 dan 2).

3. Penyuluhan penanganan, pengolahan ikan segar dan penyimpanan untuk mitra 1

4. Pembuatan kemasan dan pelabelan untuk mitra ke 2

5. Pengurusan dalam pembutan surat izin P-IRT dari Dinas Kesehatan untuk mitra 2

\section{Saran}

Diharapkan ipteks bagi masyarakat ini dapat dilanjutkan tahun berikutnya, karena melihat dari jumlah asap yang dihasilkan cukup banyak dan berpotensi untuk dijadikan acap cair, sehingga dapat digunakan kebali untuk proses pengasapan dengan mengunakan asap cair yang terbentuk.

\section{DAFTAR PUSTAKA}

Buckle, K. A., R. A. Edward, G. H. Fleet, \& M. Wooton. 1985. Ilmu Pangan. Terjemahan. Hari Purnomo. UI Press. Jakarta. 365 hal.

Data Monograf Kelurahan Simpang Tiga, Kecamatan Bukit Raya, Pemerintah Kota Pekanbaru, 2015

Satria, F. A. 2009. Studi Pembuatan Kerupuk Ikan Jambal Siam (Pangasius hypophthalmus) Dari Tepung Yang Berpengaruh Dengan Penambahan Pati Ganyong (Canna edulis Ker). Skripsi Fakultas Perikanan dan Ilmu Kelautan. Pekanbaru: Universitas Riau, 64(4) hal.

SNI (Standar Nasional Indonesia) 01-2713. 1999. Metode Pengujian Mikrobiologi Produk Perikanan : Penentuan Escherichia Coli dan Salmonella. Pusat Akreditas Badan Agribisnis Bahan Produk Makanan. Departemen Pertanian. Jakarta 17 hal.

Syarief, R. 1989. Teknologi Pengemasan Pangan. PAU Pangan dan Gizi IPB. Bogor. 